\title{
OPTIMIZATION OF MICROWAVE ASSISTED SOLID-PHASE SYNTHESIS OF OCTREOTATE PEPTIDE AND COUPLING WITH PROTECTED BIFUNCTIONAL CHELATOR DOTA $(\mathrm{tBu})_{3}$
}

\author{
ARKADIUSZ EUGENIUSZ SIKORA*, MICHAŁ MAURIN, ANTONI JAROŃ, \\ JUSTYNA PIJAROWSKA-KRUSZYNA, ŁUKASZ KORDOWSKI \\ and PIOTR GARNUSZEK
}

National Centre for Nuclear Research Radioisotope Centre POLATOM ul. Andrzeja Soltana 7, 05-400 Otwock, Poland

\begin{abstract}
This work describes the optimization of the synthesis method of DOTA-TATE peptide on solid support resin to achieve the highest purity of the raw peptide. The synthesis was facilitated with an automatic peptide synthesizer equipped with a microwave oven. The TATE peptide (Octreotate) was synthesized using N,N'diisopropylcarbodiimide (DIC) with OxymaPure as a coupling reagent to activate the amino acids. We have successfully used DIC with OxymaPure in the synthesis of TATE peptide with low amino acid racemization levels and therefore it was the first choice for protected DOTA coupling. Unreacted TATE peptide was a main impurity of the product, so the reaction of DOTA $(\mathrm{tBu})_{3}$ coupling was optimized with the help of microwave radiation. The highest purity of peptide was achieved when the coupling reaction was performed for $1 \mathrm{~h}$ at room temperature, followed by heating at $50^{\circ} \mathrm{C}$ for $30 \mathrm{~min}$. The optimal synthesis was performed at $2 \mathrm{mmol}$ (per resin) scale.
\end{abstract}

Keywords: DOTA-TATE, solid support synthesis, automated microwave-assisted synthesis

Synthetic analogs of somatostatin, the regulatory peptide responsible for important functions of the human body, are widely used in medicine. The investigations of the therapeutic utility of somatostatin analogs like DOTA-TOC and DOTA-TATE radiolabelled with ${ }^{90} \mathrm{Y}$ and ${ }^{177} \mathrm{Lu}$ in the treatment of disseminated neuroendocrine tumors (NETs) were very successful (1-4). Today, peptide receptor radionuclide therapy (PRRT) is a well-established method for the treatment of neuroendocrine tumors. DOTA-TATE (N-[[4,7,10-tris(carboxymethyl)1,4,7,10-tetraaza-cyclododec-1-yl]-D-phenylalanylL-cysteinyl-L-tyrosyl-D-tryptophyl-L-lysyl-L-threoninyl-L-cysteinyl-L-threonine, cyclic disulphide (2->7); DOTA-[D-Phe ${ }^{1}$ Tyr $^{3}$-Octreotate]; (Fig. 1) is used as a carrier molecule for ${ }^{177} \mathrm{Lu}$ or ${ }^{90} \mathrm{Y}$ radionuclides, giving together radiopharmaceutical for treatment of neuroendocrine tumors or for ${ }^{68} \mathrm{Ga}$ $\left({ }^{68} \mathrm{Ga}\right.$-DOTA-TATE) used in functional imaging of NET lesions with PET. As an active pharmaceutical ingredient (API) it needs to meet the highest quality standards specified in the European Pharmacopoeia.
In our work, DOTA-TATE peptide was synthesized on solid support polystyrene-based resin, which simplifies the process of coupling and deprotection of amino acids. The Wang polystyrene-based resin with Fmoc-Thr(tBu) exhibits remarkable thermal stability and hence a preferred resin for the future strategy with plans of automatization. The Fmoc deprotection was performed under milder basic conditions, which were safer for peptide synthesizers compared to trifluoroacetic acid which was used in the original Merrifield Boc based strategy. $\mathrm{N}, \mathrm{N}$ '-diisopropylcarbodiimide (DIC) is one of the most commonly used coupling reagent for peptide synthesis on solid support along with racemization suppressing additive like N-Hydroxybenzotriazole (HOBt) or 1-Hydroxy-7-azabenzotriazole (HOAt) (5). Relatively recently reported OxymaPure has shown excellent results in limiting the racemization of coupled amino acids $(6,7)$. TATE peptide (Octreotate) contains two cysteines, which are especially prone to racemization and can produce impurities which are difficult to remove. Therefore, we

* Corresponding author: e-mail: Arkadiusz.Sikora@polatom.pl 
<smiles>CC(O)[C@H](NC(=O)[C@H](CCCCN)NC(=O)C(Cc1c[nH]c2ccccc12)NC(=O)[C@H](Cc1ccc(O)cc1)NC(=O)C(CSSCC(NCC(=O)O)NC(=O)C(Cc1ccccc1)NC(=O)CN1CCN(CC(=O)O)CCN(CC(=O)O)CC1)NC(=O)[C@H](NC(=O)CN)C(C)O)C(=O)O</smiles>

Figure 1. DOTA-TATE peptide.

have successfully used DIC with OxymaPure in the synthesis of TATE peptide with low amino acid racemization levels and therefore it was the first choice for protected DOTA coupling.

The DOTA chelator $(1,4,7,10$-Tetraazacyclododecane-1,4,7,10-tetraacetic acid; tetraxetan) is a commonly used bifunctional chelator (BFC) for preparation of radiopharmaceutical for application in internal radionuclide therapy. It is an efficient hexadentate ligand for most transition metals including radiometals like ${ }^{177} \mathrm{Lu}$ or ${ }^{90} \mathrm{Y}$. Several methods of DOTA coupling to peptides were developed to be used under various conditions (8). DOTA can be conjugated to a peptide either in solution or on solidstate support. Water-soluble p-isothiocyanatobenzyl DOTA (p-SCN-Bn-DOTA) is often used for conjugation to antibodies via the amine group of lysine (8).

Coupling to hydrophilic peptides is performed with either N-hydroxysuccinimide (NHS) or sulfoN-Hydroxysuccinimide (sulfo-NHS) esters of DOTA in water-based solution $(8,9)$. In these cases, an active ester of DOTA can be prepared before coupling by mixing DOTA with 1-Ethyl-3-(3dimethylaminopropyl)carbodiimide and either $\mathrm{N}$ hydroxysuccinimide or sulfo-N-Hydroxysuccinimide.

For partly protected hydrophobic TATE peptide, DOTA coupling can be performed in N,Ndimethylformamide solution. In this method $\operatorname{DOTA}(\mathrm{tBu})_{3}$ is coupled to a free amine group of lysine of TATE peptide. A successful procedure of $\operatorname{DOTA}(\mathrm{tBu})_{3}$ coupling to the peptide dissolved in DMF using 1-[Bis(dimethylamino)methylene]-1H1,2,3-triazolo[4,5-b]pyridinium 3-oxide hexafluorophosphate (HATU) has been already published (10) In the above mentioned in-solution coupling an additional purification step like extraction or precipitation is required to remove unreacted substrates and by-products, which makes the procedure more time-consuming.

The publication referred above (10) mentions that the described procedure of DOTA $(\mathrm{tBu})_{3}$ coupling can be performed with a peptide bond to a solid support resin. During synthesis on solid-support, the peptide is attached to the resin, hence only rinsing with solvent is required after the reaction, making the process simpler and faster. Furthermore, solid resin helps in performing DOTA coupling in an automatic peptide synthesizer along with the synthesis of the peptide to which it is coupled. $\operatorname{DOTA}(\mathrm{tBu})_{3}$ is soluble in organic solvents used in solid-phase syntheses like N,N-dimethylformamide (DMF) or N-methylpyrrolidone (NMP) and its free carboxylic group can be activated by coupling reagents commonly used in peptide synthesis on a solid support like HATU (10).

It is possible to speed-up peptide synthesis by using microwave radiation (11-14). The microwaveassisted synthesis reduces the time needed for a standard coupling to ca. $2.5 \mathrm{~min}$ compared to $60 \mathrm{~min}$ for conventional room-temperature synthesis. 

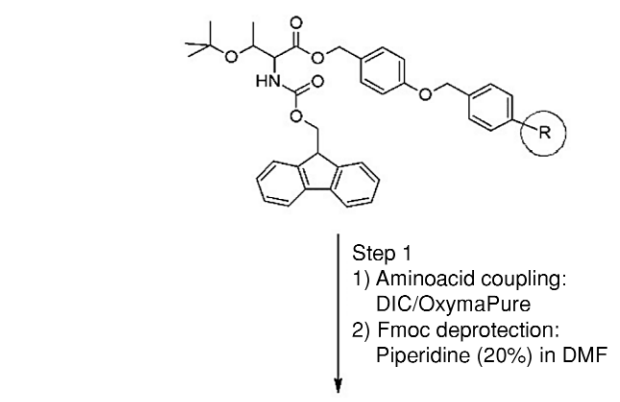

(n)

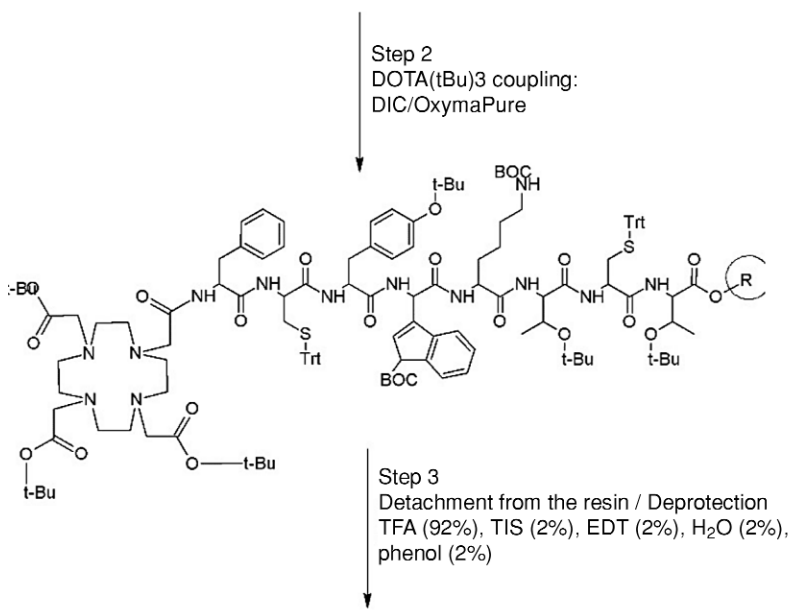

(n)

Step 4

Cyclisation

$\mathrm{H}_{2} \mathrm{O}_{2}(0.3 \%)$ in $\mathrm{NH}_{4} \mathrm{HCO}_{3}$ buffer

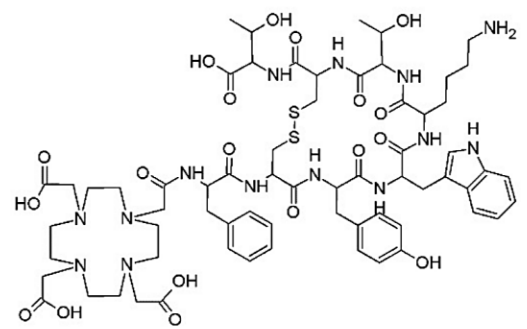

Figure 2. Synthesis of the DOTA-TATE peptide. 
The objective of our research was to optimize the synthesis of DOTA-TATE peptide using the automated solid-phase synthesis supported by microwave radiation.

\section{EXPERIMENTAL}

\section{Reagents and solvents}

Fmoc-L-Thr(tBu)-Wang resin, all amino acids, as well as coupling reagents - N,N'-diisopropylcarboxydiimide (DIC) and OxymaPure were purchased from Iris Biotech $\mathrm{GmbH}$ (Germany). Amino acids used were protected as follows: Fmoc-L-Cys(Trt), Fmoc-L-Thr(tBu), Fmoc-L-Lys(Boc), Fmoc-D$\operatorname{Trp}(\mathrm{Boc}), \quad$ Fmoc-L-Tyr(tBu), Fmoc-D-Phe. $\operatorname{DOTA}(\mathrm{tBu})_{3}$ was purchased from CheMatech (France). The purity of amino acids and the chelator was greater than $98 \%$.

Chemical Reference Substances (CRS) of TATE (TATE CRS Batch No. 01/17) and DOTATATE (DOTA-TATE CRS Batch no. 01/19) were prepared at NCBJ RC POLATOM (Poland) and were characterized according to the requirements of the European Pharmacopoeia (Ph. Eur.). These CRSs were used for identification and assays tests. All other reagents were purchased either from Iris Biotech GmbH (Germany) or Sigma-Aldrich (Germany). Solvents were purchased from Avantor Performance Materials Poland S.A. (Poland).

\section{Peptide synthesis}

Manual peptide synthesis on solid support was performed in a glass reaction vessel for peptide synthesis with frit for stirring by nitrogen bubbling. The synthesis was performed in a small scale $(0.3 \mathrm{mmol})$ to find out how much time is required to couple the protected DOTA. The resin was swollen using dichloromethane (DCM) and reactions were carried out in N,N-dimethylformamide (DMF) as a solvent. Stirring during the reactions and resin washing was done using nitrogen.

Automatic peptide synthesis on solid support was carried out using Liberty Blue automatic synthesizer (CEM) equipped with Discover microwave oven. The oven has a single-mode microwave cavity $(300 \mathrm{~mL})$, capable of using reaction vessels up to $125 \mathrm{~mL}$. Maximum power of the oven is $300 \mathrm{~W}$. The reaction mixture was stirred by nitrogen bubbling. The temperature was controlled using IR fibre-optic sensor connected to the Liberty Blue unit.

The peptide synthesis scheme is shown in Figure 2.

The peptide was formed on the polystyrene Wang resin. The resin was purchased preloaded with Fmoc-Thr(tBu). It was swollen in dichloromethane and placed in the reaction vessel before commencing the reaction.

Before amino acid coupling, the Fmoc deprotection of the previous amino acid residing on the resin was done using a solution of piperidine $(20 \%)$ in N,N-dimethylformamide. For each coupling step an appropriate amino acid (3 mol. equiv. per resin) was activated using N,N'-diisopropylcarbodiimide (3 mol equiv. per resin) with OxymaPure (3 mol equiv. per resin). A double amount (6 mol equiv. per resin) of OxymaPure was used to minimize the risk of racemization of Fmoc-L-Cys(Trt) $(6,7)$. Between Fmoc deprotection and amino acid coupling, the resin was thoroughly washed with solvent. Automatic amino acid coupling and Fmoc deprotec-

Table 1. Conditions for manual solid support peptide synthesis.

\begin{tabular}{|l|c|c|}
\hline \multicolumn{1}{|c|}{ Reaction } & $\begin{array}{c}\text { Temperature } \\
{\left[{ }^{\circ} \mathrm{C}\right]}\end{array}$ & $\begin{array}{c}\text { Time } \\
{[\mathrm{s}]}\end{array}$ \\
\hline Amino acid coupling & 25 & 3600 \\
\hline Fmoc deprotection & 25 & 3600 \\
\hline
\end{tabular}

Table 2. Conditions for microwave-assisted solid support peptide synthesis (scale $0.1 \mathrm{mmol}$ ).

\begin{tabular}{|l|c|c|c|c|}
\hline \multicolumn{1}{|c|}{ Reaction } & $\begin{array}{c}\text { Reaction } \\
\text { step }\end{array}$ & $\begin{array}{c}\text { Temperature } \\
{\left[{ }^{\circ} \mathrm{C}\right]}\end{array}$ & $\begin{array}{c}\text { Microwave power } \\
{[\mathrm{W}]}\end{array}$ & $\begin{array}{c}\text { Time } \\
{[\mathrm{s}]}\end{array}$ \\
\hline Amino acid coupling (except \\
Fmoc-LCys(Trt)-OH) & 1 & 70 & 150 & 30 \\
\hline \multirow{2}{*}{ Fmoc-LCys(Trt) coupling } & 2 & 90 & 30 & 120 \\
\cline { 2 - 5 } & 1 & 25 & 35 & 240 \\
\hline \multirow{2}{*}{ Fmoc deprotection } & 2 & 50 & 125 & 25 \\
\cline { 2 - 5 } & 2 & 70 & 30 & 65 \\
\hline
\end{tabular}


tion were performed based on protocols supplied in LibertyBlue peptide synthesizer control software (CEM) (14, 15). Initially, the synthesis was performed in a small scale $(0.1 \mathrm{mmol})$ to find an optimal temperature for protected DOTA coupling. When this was established, the scale of the synthesis was increased to manufacturing needs level (1.0 $2.5 \mathrm{mmol}$ ) while evaluating synthesis yield in this range. The conditions of amino acid coupling and Fmoc removal reactions are shown in Table 1 for manual synthesis and in Table 2 for automated synthesis. In the case of the manual synthesis, the time of Fmoc deprotection was extended to $1 \mathrm{~h}$ to exclude any possibility of amino acid deletion in the next coupling cycle.

Cysteines are especially prone to racemization. The Fmoc-L-Cys(Trt) automatic coupling was performed under milder conditions compared to other amino acids and the molar excess of OxymaPure was twice compared to other amino acids, in order to suppress racemization as much as possible.

Once synthesis was completed, the resin was washed with N,N-dimethylformamide and dichloromethane and then dried overnight under vacuum. The cleavage and deprotection step was carried out at room temperature for $6 \mathrm{~h}$. The deprotection step was carried out on the basis of the published procedure (16). The deprotecting solution was prepared by mixing trifluoroacetic acid with additions of $2 \%$ vol. triisopropylsilane, $2 \%$ vol. phenol, $2 \%$ vol. water and $2 \%$ vol. 1,2-ethanedithiol. 40 $\mathrm{mL}$ of the above described deprotecting solution per $1 \mathrm{mmol}$ of resin was placed in a flask with the peptide attached to the resin and stirred. The time needed for deprotection was chosen according to the published method (16). The deprotected peptide was precipitated and washed with diethyl ether. An additional deprotection step with a diluted aqueous TFA solution is required to completely remove Boc protecting groups from tryptophane (5). The peptide was dissolved in an aqueous TFA solution $(0.1 \%)$ to achieve a peptide concentration of $5 \mu \mathrm{mol} / \mathrm{mL}$. The solution of the peptide was stirred in a rotary evaporator at $60^{\circ} \mathrm{C}$, under reduced pressure (800 mbar) for $1 \mathrm{~h}$. Apart from completing the deprotection of tryptophane, the reduced pressure helps to remove the remaining diethyl ether from the mixture. The solution of the fully deprotected peptide was then frozen on dry ice and lyophilized.

The disulfide bridge (cyclization, step 4) was formed by oxidation of cysteines as previously described $(9,17)$. The linear DOTA-TATE peptide was dissolved at a concentration of $(1 \mathrm{mg} / \mathrm{mL})$ in ammonium carbonate buffer $(0.1 \mathrm{M}, \mathrm{pH} \sim 8)$. The thiol groups of cysteines were oxidized by the dropwise addition of 5-fold molar excess of hydrogen peroxide as a diluted solution $(0.3 \%)$ in water, into the peptide solution while stirring. After the full quantity of hydrogen peroxide was added, the reaction was further continued for $10 \mathrm{~min}$ and then terminated by acidification of the aqueous solution of acetic acid (10\%). The excess of hydrogen peroxide was then removed on the Sep-Pak C18 column (Waters Corp. USA). The column was rinsed with water. The peptide was eluted with a mixture of acetonitrile (66.6\%), water $(33.3 \%)$, trifluoroacetic acid $(0.1 \%)$. The solution of raw DOTA-TATE was frozen and lyophilized.

During the scale-up experiment, the DOTA coupling efficiency and the racemization level were calculated.

\section{Calculations}

The yield of synthesis was calculated from the following equation:

Yield of sybthesis $=\frac{\text { Raw peptide mass } \times \text { Chromatographic purity/Molar mass of peptide }}{\text { Batch size }} \times 100$

The molar mass of DOTA-TATE peptide $=$ $1436 \mathrm{~g} / \mathrm{mol}$.

Efficiency of DOTA coupling was calculated from the following equation:

DOTA coupling efficiency $=\frac{\text { DOTA }- \text { TATE content }[\%]}{\text { DOTA }- \text { TATE content }[\%]+\text { TATE content }[\%]} \times 100$

Racemization level was calculated from the following equation:

Racemization level $=\frac{\text { Racemized DOTA }- \text { TATE }[\%]}{\text { DOTA }- \text { TATE }}$ Racemized DOTA - TATE [\%]
- TATE content [\%] + Racemized DOTA - TATE content [\%]

\section{Analytical HPLC}

The purity of raw DOTA-TATE peptide was measured using an analytical HPLC system consisting of the following modules: two LC-20AD pumps, DGU-14A degasser, SIL-20AC HT autosampler, CTO-10AS VP column oven, and SPD-10A UVVIS detector, made by Shimadzu Corp. (Japan). The Clarity chromatography software from DataApex (Czech Republic) was used to control the chromatography system and for data processing. Column: Kinetex C18 (5 um, $150 \times 4.6$ mm, $100 \AA)$ from Phenomenex (USA). Elution was performed with an acetonitrile-water gradient: 5-50\% AcN 0$25 \mathrm{~min}, 50-5 \%$ AcN 25-30 min, 5\% AcN 30-40 min. Solvents were added with $0.1 \%$ TFA as a counterion. Detection: UV measurement at $220 \mathrm{~nm}$. Flow rate: $0.8 \mathrm{~mL} / \mathrm{min}$. Oven temperature: $30^{\circ} \mathrm{C}$.

\section{LC-MS analysis}

LC-MS analysis was run on Shimadzu (Japan) HPLC Prominence system equipped with a mass 
spectrometer LCMS-IT-TOF (Shimadzu) system consisting of electrospray source (ESI), ion trap (IT), time of flight analyzer (TOF), and the LCMS Solution software.

Samples were injected onto the Phenomenex Kinetex C18 column $(5 \mu \mathrm{m}, 150 \times 4.6 \mathrm{~mm}, 100 \AA)$ and chromatographed using the following mobile phases: A: $0.05 \%$ TFA in water; B: $0.05 \%$ TFA in acetonitrile. The gradient profile was as follows: (i) 0-25 min - linear gradient from 5 to $50 \% \mathrm{~B}$, (ii) 25 30 min - linear gradient from 50 to $95 \%$ B, (iii) 30 $35 \mathrm{~min}-95 \% \mathrm{~B}$, (iv) $35-45 \mathrm{~min}-95$ to $5 \% \mathrm{~B}$, and finally, (v) $45-50 \mathrm{~min}-5 \% \mathrm{~B}$. Flow rate of 0.8 $\mathrm{mL} / \mathrm{min}$, oven temperature of $30^{\circ} \mathrm{C}$ and UV detection at $220 \mathrm{~nm}$ were used.

The conditions of mass spectrometry analysis were as follows: ionization: electrospray; ionization mode: positive; interference voltage: $5.0 \mathrm{kV}, \mathrm{CDL}$ temperature: $270^{\circ} \mathrm{C}$; heat block temperature: $270^{\circ} \mathrm{C}$; nebulizing gas flow: $1.5 \mathrm{~L} / \mathrm{min}$; mass range $\mathrm{m} / \mathrm{z}$ : 200-1500 Da and ion accumulation: $30 \mathrm{~ms}$.

\section{Raman spectroscopy}

Raman spectra were collected with a dispersive spectrometer Labram HR800 (Horiba Jobin-Yvon), equipped with a confocal microscope system (Olympus BX40) and a Peltier-cooled CCD detector (1024 x 256 pixel). Diode-pumped, frequency-doubled Nd:YAG laser, emitting $532 \mathrm{~nm}$ wavelength was used as an excitation source. The confocal pinhole size was set to $200 \mu \mathrm{m}$ and the holographic grating with 600 grooves $\mathrm{mm}^{-1}$ was applied. Calibration of the instrument was performed using a $520 \mathrm{~cm}^{-1}$ Raman signal of a silicon wafer.

Raman measurements were carried out in the backscattering configuration, using a sample in the powder form. Spectra were acquired employing a 50 x magnification Olympus objective, with a laser power below $3 \mathrm{~mW}$ on the sample. Raman signal was typically collected to cover the two spectral windows: 200-1800 $\mathrm{cm}^{-1}$ and 2400-4000 $\mathrm{cm}^{-1}$. Within these two spectral ranges, one can detect the Raman bands corresponding to vibrational modes of particular interest to identify the form of the examined compounds (namely stretching vibrations of S$\mathrm{S}$ and SH moieties).

\section{Amino acid sequencing / optical purity:}

Amino acid sequencing and optical purity tests were performed at C.A.T GmbH Germany. Test for racemization of amino acids in the peptide was performed by GC-MS method. The second unambiguous quantitation of racemate involved hydrolysis with $6 \mathrm{~N} \mathrm{D}_{2} \mathrm{O} / \mathrm{DCl}$. The amino acids were deriva- tized using deuterated reagents. Racemization during this sample preparation was accompanied by deuterion exchange in the apposition (deuterium label). The proportion of D-amino acid originally present in the peptide was monitored by mass spectrometry. The limit of quantitation of the method is $0.1 \%$ of the enantiomeric antipode with the standard deviation $<0.1 \%$.

The verification of the peptide sequence was performed by direct injection into the mass spectrometer using electrospray ionization. After selective disulfide cleavage with DTT, the peptide was dissolved in Acetonitrile/ $\mathrm{H}_{2} \mathrm{O} 1: 1 \quad(0.1 \%$ formic acid) and was injected into the ESI Q-TOF system.

\section{Preparative HPLC}

Preparative HPLC was run on a Shimadzu (Japan) system, consisting of an LC-20AP pump, an SPD-20A UV/VIS detector, a CBM-2A controller system, a fraction collector FRC-10A and the LC Solution software.

The crude peptide $(1.5$ and $2.0 \mathrm{mmol}$ batch size) was purified by preparative HPLC on the Phenomenex Luna C18(2) column (15 $\mu \mathrm{m}, 250 \times 50$ $\mathrm{mm}, 100 \AA$ ) with $\mathrm{C} 18(2)$ precolumn $(15 \times 50 \mathrm{~mm})$. A gradient reverse-phase method with the following two mobile phases was used: A: $0.1 \%$ TFA in water; B: $0.1 \%$ TFA in acetonitrile. The gradient profile and timing were: (i) 0-100 min - linear gradient from 0 to $35 \% \mathrm{~B}$, followed by (ii) 100-105 $\mathrm{min}-$ linear gradient from $35 \%$ to $0 \% \mathrm{~B}$. Flow rate of 35 $\mathrm{mL} / \mathrm{min}$ and UV detection at $220 \mathrm{~nm}$ were used. The sample of crude DOTA-TATE (ca. $500 \mathrm{mg}$ ) in $5 \mathrm{~mL}$ of water was injected onto the HPLC system. The $5 \mathrm{~mL}$ fractions containing DOTA-TATE were collected and lyophilized. The lyophilized fractions of DOTA-TATE were weighted and their purity was assessed by analytical HPLC method.

The identity of each DOTA-TATE fraction was confirmed by comparing the retention time of the main peak on the HPLC chromatograms with the retention time of the DOTA-TATE standard.

\section{RESULTS AND DISCUSSION}

\section{Manual peptide synthesis}

The manual peptide synthesis performed in the $0.3 \mathrm{mmol}$ scale resulted in a peptide of $68.3 \%$ purity (Fig. 3).

To optimize TATE and DOTA $(\mathrm{tBu})_{3}$ coupling, several manual syntheses were carried out to assess time, efficiency and purity parameters. During each experiment, the different time of DOTA $(\mathrm{tBu})_{3}$ coupling was tested. The raw DOTA-TATE peptide 
obtained was analyzed by RP-HPLC method. For each sample, both chromatographic purity (DOTATATE/ Free TATE content) and DOTA coupling efficiency were evaluated. The results are presented in Table 3.

The findings indicate that the reaction time between $60 \mathrm{~min}$ and $120 \mathrm{~min}$ result in a high-quality product with a remarkable balance of purity and DOTA coupling efficiency. For further work, the reaction was carried out for $60 \mathrm{~min}$ at room temperature and continued for $30 \mathrm{~min}$ with microwave heating.

\section{Identification of the synthesized DOTA-TATE and impurities}

The identity of DOTA-TATE was confirmed by LC-MS study and amino acid sequencing. Additionally, the formation of a disulfide bridge

Table 3. DOTA(tBu)3 coupling in manual synthesis.

\begin{tabular}{|c|c|c|c|c|}
\hline Exp & $\begin{array}{c}\text { Time } \\
\text { duration } \\
{[\mathrm{min}]}\end{array}$ & $\begin{array}{c}\text { DOTA-TATE } \\
\text { content } \\
{[\%]}\end{array}$ & $\begin{array}{c}\text { Free TATE } \\
\text { content } \\
{[\%]}\end{array}$ & $\begin{array}{c}\text { DOTA coupling } \\
\text { efficiency } \\
{[\%]}\end{array}$ \\
\hline 1 & 15 & 53.3 & 27.1 & 66.3 \\
\hline 2 & 30 & 61.7 & 18.2 & 77.2 \\
\hline 3 & 60 & 68.3 & 4.8 & 93.4 \\
\hline 4 & 120 & 63.3 & 0.8 & 98.7 \\
\hline
\end{tabular}

Table 4. LC-MS data of crude DOTA-TATE.

\begin{tabular}{|c|c|c|c|c|c|}
\hline Compound & Rt $[\mathrm{min}]$ & HPLC $[\%]$ & $\mathrm{m} / \mathrm{z} \mathrm{obs}$. & Assignment & $\mathrm{m} / \mathrm{z} \mathrm{calc.}$ \\
\hline A & 13.4 & 0.5 & $718.25[\mathrm{M}+2 \mathrm{H}]^{2+}$ & $\begin{array}{c}\text { racemized } \\
\text { DOTA-TATE }\end{array}$ & $\begin{array}{c}718.30[\mathrm{M}+2 \mathrm{H}]^{2+} \\
1435.60[\mathrm{M}+\mathrm{H}]^{+}\end{array}$ \\
\hline B & 13.8 & 49.2 & $\begin{array}{c}718.25[\mathrm{M}+2 \mathrm{H}]^{2+} \\
1435.50[\mathrm{M}+\mathrm{H}]^{+}\end{array}$ & DOTA-TATE & $\begin{array}{c}718.30[\mathrm{M}+2 \mathrm{H}]^{2+} \\
1435.60[\mathrm{M}+\mathrm{H}]^{+}\end{array}$ \\
\hline C & 14.1 & 0.3 & $525.18[\mathrm{M}+2 \mathrm{H}]^{2+}$ & TATE & $525.21[\mathrm{M}+2 \mathrm{H}]^{2+}$ \\
\hline D & 14.7 & 2.7 & $1029.35[\mathrm{M}+3 \mathrm{H}]^{3+}$ & - & $771.32[\mathrm{M}+2 \mathrm{H}]^{2+}$ \\
\hline E & 15.1 & 6.7 & $771.27[\mathrm{M}+\mathrm{H}]^{+}$ & $\begin{array}{c}\text { DOTA-TATE-p- } \\
\text { hydroxybenzyl }\end{array}$ & - \\
\hline F & 15.7 & 7.8 & $1012.70[\mathrm{M}+3 \mathrm{H}]^{3+}$ & - & - \\
\hline G & 16.7 & 3.7 & $825.29[\mathrm{M}+2 \mathrm{H}]^{2+}$ & - & - \\
\hline H & 17.1 & 2.5 & $820.41[\mathrm{M}+\mathrm{H}]^{+}$ & - & - \\
\hline I & 17.3 & 2.3 & $800.80[\mathrm{M}+2 \mathrm{H}]^{2+}$ & - & - \\
\hline J & 17.5 & 2.3 & $800.30[\mathrm{M}+2 \mathrm{H}]^{2+}$ & - & - \\
\hline K & 18.6 & 1.7 & $775.3[\mathrm{M}+2 \mathrm{H}]^{2+}$ & - & - \\
\hline
\end{tabular}

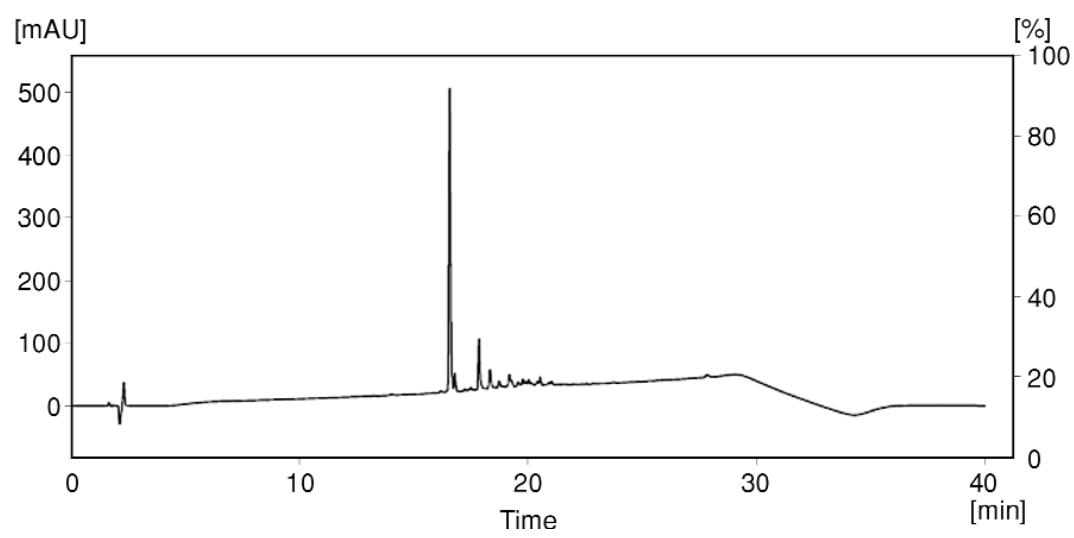

Figure 3. HPLC chromatogram of crude DOTA-TATE peptide $0.3 \mathrm{mmol}$ scale, manual synthesis. 
during the cyclization of the peptide was confirmed by the Raman spectroscopy. The main impurities of the DOTA-TATE peptide (Rt $13.8 \mathrm{~min}$ ) were identified by mass spectroscopy. (Fig. 4, Table 4)

The impurity A revealed the same mass as the main product so it was isolated by the preparative HPLC method and again analyzed by MS method resulting in the +3 charged 479.19 mass signal (Fig. 5) after calculation 1435.60 the mass of the DOTATATE peptide. The sample was additionally analyzed (C.A.T. GmbH) for amino acid sequence and amino acid optical purity. The analysis (resulted in quantification of amino acid enantiomers: L-Thr 99.7\%; D-Cys 39.9\%; L-Phe 1.08\%; D-Tyr 0.84\%; D-Lys $0.39 \%$; L-Trp $0.66 \%$ ) confirmed that the impurity A is the DOTA-TATE peptide with racemized cysteine.

The signal C (Rt $14.1 \mathrm{~min}$ ) was identified by mass calculation $(\mathrm{m} 2+525.21)$ as TATE peptide (no DOTA chelator conjugated) what was confirmed by Rt of previously synthesized TATE reference peptide (Fig. 4).

Those two identified impurities are the most essential ones when it comes to the purification step. The first preparative HPLC purification attempts showed that when larger amounts of a peptide are applied on the preparative c18 column the racemate and TATE impurities coelute in the front and tail fractions lowering the overall yield of the final product of the specified purity above $97 \%$. To overcome this problem the maximum acceptable amount of the racemized peptide during the synthesis was assumed to be $1 \%$ and the optimization of the DOTA chelator conjugation was performed.

For the coupling reactions, the OxymaPure as a protective agent was successively used $(6,7)$. The level of cysteine racemization was in low acceptable below $0.5 \%$ range.

Impurity E (Rt $15.1 \mathrm{~min}$ ) revealed the mass of molecular ion with an increased molecular weight of ca. 106 Da compared to DOTA-TATE. This mass corresponds to the DOTA-TATE peptide conjugated with p-hydroxybenzyl group derived from the decomposition of Wang resin during the TFA cleavage step. This phenomenon was previously described in the literature (20).

\section{Automatic peptide synthesis}

The manual synthesis process was transitioned to the automatic microwave synthesizer. According

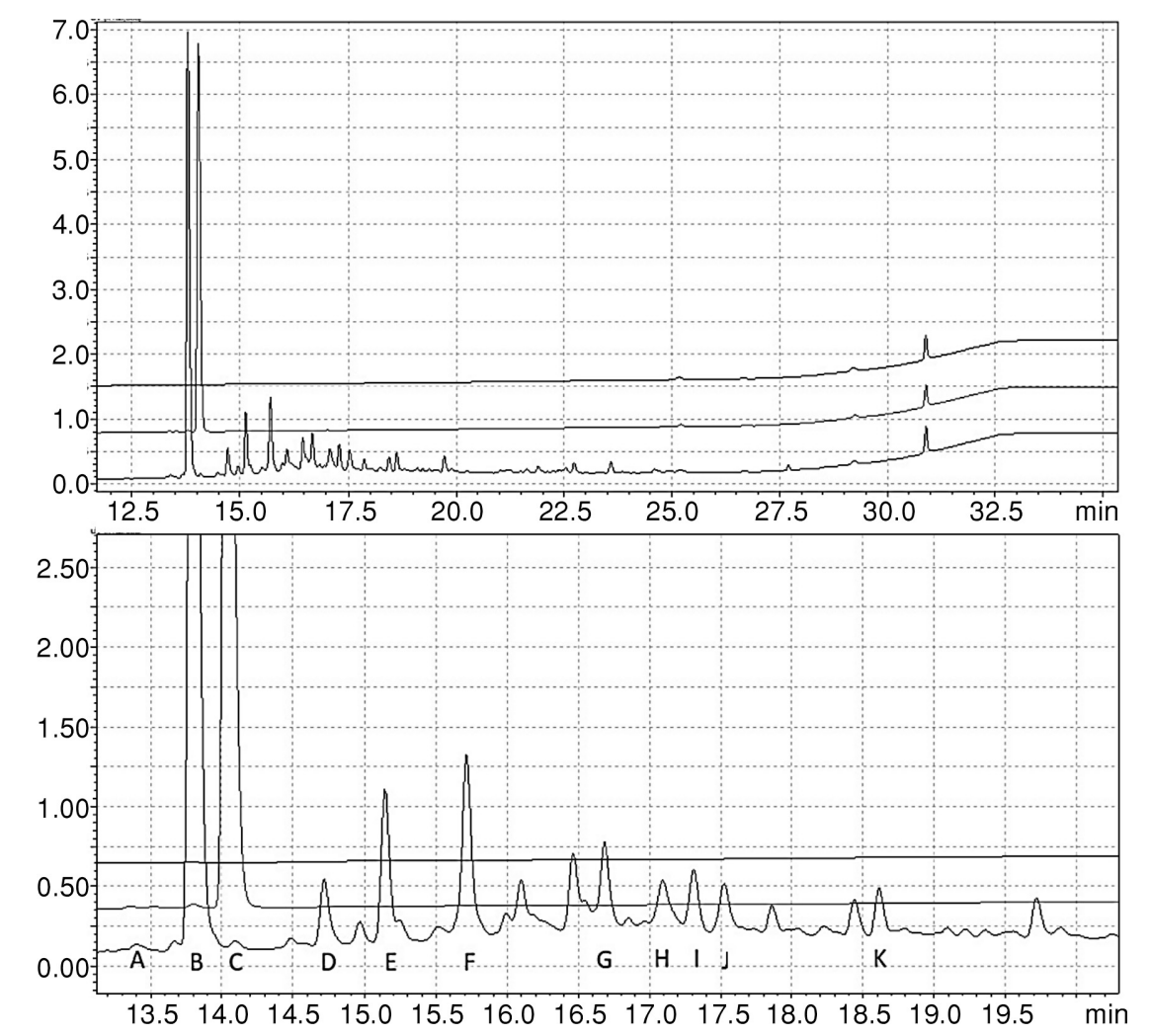

Figure 4. LC chromatograms of DOTA-TATE: I (upper line) - blank; II (middle line) -TATE CRS Chemical Reference Standard, produced in OR Polatom (Poland) $(100 \mu \mathrm{g} / \mathrm{mL})$; III (bottom line)- $1.0 \mathrm{mmol}$ batch size $(400 \mu \mathrm{g} / \mathrm{mL})$. 


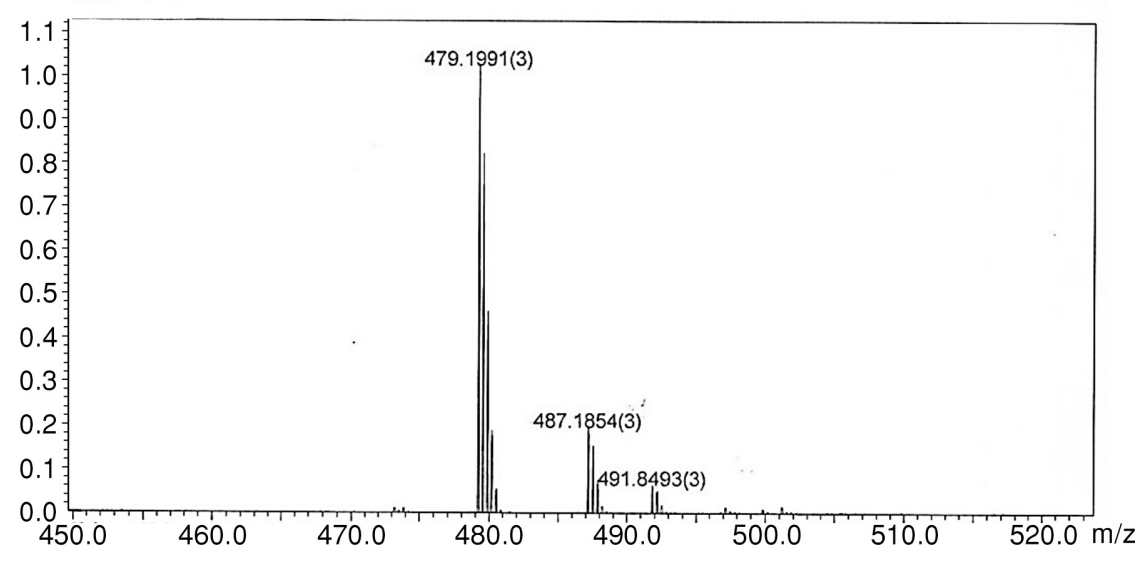

Figure 5. The mass spectrum of the isolated impurity A with retention time $13.4 \mathrm{~min}$.

Table 5. Optimization of DOTA $(\mathrm{tBu})_{3}$ automatic coupling conditions (microwave power $35 \mathrm{~W}$ ).

\begin{tabular}{|c|c|c|c|c|c|c|}
\hline Exp & React. Step & Temperature $\left[{ }^{\circ} \mathrm{C}\right]$ & Time [min] & $\begin{array}{c}\text { DOTA-TATE } \\
\text { content } \\
{[\%]}\end{array}$ & $\begin{array}{c}\text { Free TATE } \\
\text { content } \\
{[\%]}\end{array}$ & $\begin{array}{l}\text { DOTA coupling } \\
\text { efficiency } \\
{[\%]}\end{array}$ \\
\hline 1 & 1 & 25 & 90 & 80.4 & 5.5 & 93.6 \\
\hline 2 & $\begin{array}{l}1 \\
2\end{array}$ & $\begin{array}{l}25 \\
40\end{array}$ & $\begin{array}{l}60 \\
30\end{array}$ & 83.4 & 2.8 & 96.7 \\
\hline 3 & $\begin{array}{l}1 \\
2\end{array}$ & $\begin{array}{l}25 \\
50\end{array}$ & $\begin{array}{l}60 \\
30\end{array}$ & 87.2 & 2.0 & 97.7 \\
\hline 4 & $\begin{array}{l}1 \\
2\end{array}$ & $\begin{array}{l}25 \\
60\end{array}$ & $\begin{array}{l}60 \\
30\end{array}$ & 83.8 & 3.0 & 96.5 \\
\hline 5 & $\begin{array}{l}1 \\
2\end{array}$ & $\begin{array}{l}25 \\
75\end{array}$ & $\begin{array}{l}60 \\
30\end{array}$ & 67.1 & 0.7 & 99.0 \\
\hline
\end{tabular}

to literature (18), microwave heating helps to speedup the coupling reactions but may increase the racemization of amino acids, especially cysteine and histidine. That is why OxymaPure was used as the protective agent (5). During the study, in order to prevent racemization, the amount of OxymPure used was twice compared to reference publication (18). Various parameters of reaction time and temperature were tested for optimal results. The results of the experiment are summarized in Table 5.

The conjugation parameters used in experiment 3 (Table 4) gave the best results in terms of a minimal amount of impurities. It was observed that the optimal temperature range is from $40^{\circ} \mathrm{C}$ to $60^{\circ} \mathrm{C}$. The best results were archived at $50^{\circ} \mathrm{C}$ when the purity of raw DOTA-TATE peptide was increased to $87.2 \%$. At room temperature a significant fraction of peptide did not react; leaving $5.5 \%$ of unreacted TATE peptide (Exp. 1). On the other hand, when the temperature was increased above $60^{\circ} \mathrm{C}$, the amount of free TATE decreased to as low as $0.7 \%$ at $75^{\circ} \mathrm{C}$, but the product's overall purity drops significantly. As mentioned in the literature (19), in the initial procedure of DOTA coupling to peptides the time required to complete the reaction was $72 \mathrm{~h}$ and involved additional complex purification steps such as separation on silica columns. The protected DOTA coupling method developed in this work takes the reaction time of $1 \mathrm{~h} 30 \mathrm{~min}$ and benefits from a simpler separation of a resin-bound peptide. The racemization level of cysteine in the microwave synthesis process was maintained at the same level as during the conventional synthesis thus proving the protocol with the use of OxymaPure to be effective in microwave conditions.

\section{Scaling-Up}

The reaction conditions from Experiment 3 of Table 4 (reaction at room temperature for $1 \mathrm{~h}$ and then additional microwave heating at $50^{\circ} \mathrm{C}$ for 30 min) were selected for DOTA $(\mathrm{tBu})_{3}$ coupling in the batch scale-up study. Using N,N-diisopropylcar- 
bodiimide with OxymaPure and microwave radiation helped to reduce the time required DOTA $(\mathrm{tBu}) 3$ coupling to $1 \mathrm{~h} 30 \mathrm{~min}$ compared to presented in the literature (19).

The maximum batch size was established by performing the synthesis in several scales from 1.0 mmol to $2.5 \mathrm{mmol}$, using the $125 \mathrm{~mL}$ reaction vessel. For each batch, the purity of the peptide was evaluated by the HPLC method. The results are collected in Table 6.

From the data in Table 6, it is clearly seen that the highest yield of synthesis is achieved in the case of $1.5 \mathrm{mmol}$ batch size. For a batch size of 2.5 mmol, a significant drop in the purity of the product was observed. The purity decrease of the product with the increase of the batch size and the differences between two batches of the same 2.5 mmolar scale probably depends on the resin loading, which when low forces to use the higher mass of resin for the same amount of mmoles. In our case, we had resins with relatively low loading (0.32-0.52 $\mathrm{mmol} / \mathrm{g}$ ). The bulky mass of the resin in the reaction vessel affects stirring, transport of the reagents and the heat distribution. It can be assumed that in the

Table 6. The parameters of up-scaled batches.

\begin{tabular}{|c|c|c|c|c|c|c|}
\hline $\begin{array}{c}\text { Batch } \\
\text { size } \\
{[\mathrm{mmol}]}\end{array}$ & $\begin{array}{c}\text { Resin } \\
\text { loading } \\
{[\mathrm{mmol} / \mathrm{g}]}\end{array}$ & $\begin{array}{c}\text { Raw peptide } \\
\text { purity } \\
{[\%]}\end{array}$ & $\begin{array}{c}\text { Raw } \\
\text { peptide } \\
{[\mathrm{mg}]}\end{array}$ & $\begin{array}{c}\text { Yield of } \\
\text { synthesis } \\
{[\%]}\end{array}$ & $\begin{array}{c}\text { DOTA } \\
\text { coupling } \\
\text { efficiency [\%] }\end{array}$ & $\begin{array}{c}\text { DOTA-TATE } \\
\text { racemization } \\
\text { level [\%] }\end{array}$ \\
\hline 1.0 & 0.32 & 42.6 & 957 & 37.4 & 98.6 & 0.5 \\
\hline 1.5 & 0.32 & 78.1 & 1674 & 60.7 & 98.7 & 0.4 \\
\hline 2.0 & 0.32 & 76.8 & 1990 & 53.2 & 99.3 & 0.4 \\
\hline 2.5 & 0.35 & 36.0 & 2122 & 21.3 & 96.5 & - \\
\hline 2.5 & 0.52 & 53.9 & 2109 & 31.7 & 89.5 & 0.5 \\
\hline
\end{tabular}
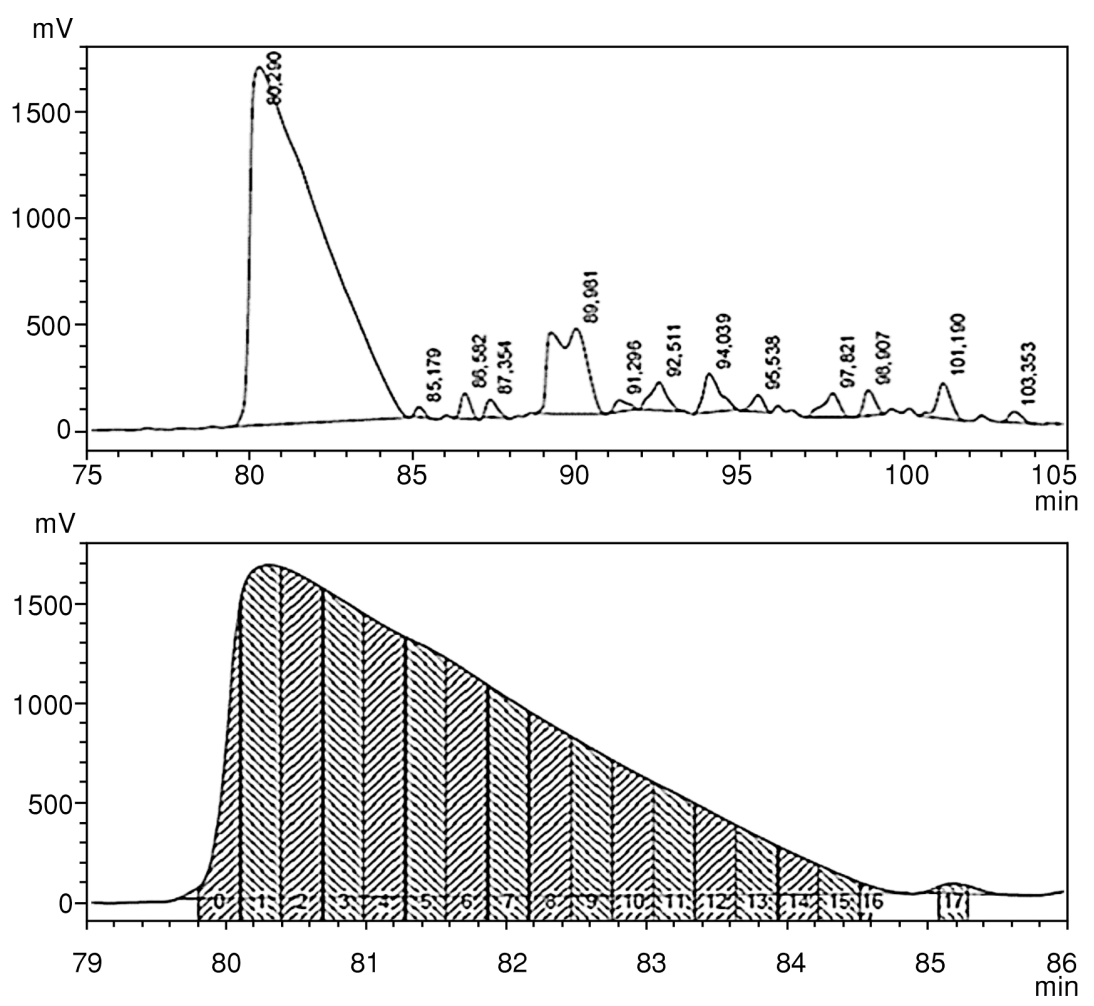

Figure 6. The typical preparative HPLC chromatogram of DOTA-TATE ( 2 mol batch size). The resolution between the peak of DOTATATE $(\mathrm{Rt}=80.3 \mathrm{~min})$ and the peak of impurity $(\mathrm{Rt}=85.2 \mathrm{~min})$. 
Table 7. Batch data for DOTA-TATE bulk.

\begin{tabular}{|c|c|c|c|c|c|}
\hline \multirow{2}{*}{ Test } & \multirow{2}{*}{ Requirements } & \multirow{2}{*}{ Methods } & \multicolumn{3}{|c|}{ Results } \\
\hline & & & $4 / 17$ & $98 / 19$ & $202 / 19$ \\
\hline $\begin{array}{l}\text { Appearance } \\
\text { (form and color) }\end{array}$ & White powder & Visual & Conforms & Conforms & Conforms \\
\hline $\begin{array}{l}\text { Identification: } \\
\text {-Mass spectrum }\end{array}$ & $\begin{array}{l}\text { Ion }[\mathrm{M}+\mathrm{H}]^{+} 1435.6 \pm 1.0 \\
\text { or }[\mathrm{M}+2 \mathrm{H}]^{2+} 718.3 \pm 1.0\end{array}$ & MS & 718.2 & 718.2 & 718.2 \\
\hline -IR spectrum & $\begin{array}{l}\text { The spectrum conforms } \\
\text { to the spectrum of the } \\
\text { DOTATATE CRS }\end{array}$ & $\mathrm{IR}$ & Conforms & Conforms & Conforms \\
\hline -HPLC & $\begin{array}{l}\text { The retention time } \\
\text { conforms to the retention } \\
\text { time of DOTATATE } \\
\text { CRS }(+/-5 \%)\end{array}$ & HPLC & $\begin{array}{l}\text { Conforms } \\
\left(\mathrm{R}_{\mathrm{T}} 1.00\right)\end{array}$ & $\begin{array}{l}\text { Conforms } \\
\left(\mathrm{R}_{\mathrm{T}} 1.00\right)\end{array}$ & $\begin{array}{l}\text { Conforms } \\
\left(\mathrm{R}_{\mathrm{T}} 1.00\right)\end{array}$ \\
\hline $\begin{array}{l}\text { Purity: } \\
\text {-Peptide purity } \\
\text {-Each unspecified }\end{array}$ & $\begin{array}{l}\geq 97 \% \\
\leq 1.5 \%\end{array}$ & HPLC & $\begin{array}{l}99.7 \% \\
0.3 \%\end{array}$ & $\begin{array}{l}99.1 \% \\
0.8 \%\end{array}$ & $\begin{array}{l}99.5 \% \\
0.3 \%\end{array}$ \\
\hline $\begin{array}{l}\text { Assay: } \\
\text { - Net peptide }\end{array}$ & $\geq 75 \%$ & HPLC & $78.6 \%$ & $78.6 \%$ & $75.0 \%$ \\
\hline $\begin{array}{l}\text { Other tests: } \\
\text {-Trifluoroacetic acid } \\
\text {-Water } \\
\text {-Residual solvent: } \\
\text { acetonitrile } \\
\text {-Endotoxin content } \\
\text {-Bioburden }\end{array}$ & $\begin{array}{l}\text { To be reported } \\
\leq 10.0 \% \\
\leq 410 \mathrm{ppm} \\
<10 \mathrm{IU} / \mathrm{mg} \\
\leq 10 \mathrm{CFU} / \mathrm{mg}\end{array}$ & $\begin{array}{c}\text { IC } \\
\text { Karl-Fisher } \\
\text { GC } \\
\text { LAL (Gel - clot }) \\
\text { Membrane filtration }\end{array}$ & $\begin{array}{c}20.2 \% \\
2.2 \% \\
<8 \mathrm{ppm} \\
<1.25 \mathrm{IU} / \mathrm{mg} \\
6 \mathrm{CFU} / \mathrm{mg}\end{array}$ & $\begin{array}{c}19.3 \% \\
3.3 \% \\
<10 \mathrm{ppm} \\
<0.625 \mathrm{IU} / \mathrm{mg} \\
0 \mathrm{CFU} / \mathrm{mg}\end{array}$ & $\begin{aligned} & 19.8 \% \\
& 3.7 \% \\
&<10 \mathrm{ppm} \\
& \\
&<0.625 \mathrm{IU} / \mathrm{mg} \\
& 2 \mathrm{CFU} / \mathrm{mg}\end{aligned}$ \\
\hline
\end{tabular}

case of Liberty Blue automatic peptide synthesizer the maximum batch size should not exceed 2.0 mmol of resin when using the resin with loading below $0.5 \mathrm{mmol} / \mathrm{g}$.

It is noteworthy that the scale of automated microwave synthesis of DOTA-TATE does not influence the racemization, which in our experiments stayed at a constant level (max. $0.5 \%)$.

\section{Purification}

The upscaled batch has been purified by preparative HPLC method. $500 \mathrm{mg}$ of the crude peptide was injected in an individual run of the HPLC column. The exemplary UV chromatogram of purification $500 \mathrm{mg}$ of DOTA has been shown in Figure 6.

Generally, all fractions except the first and last met the specified acceptance criteria (purity $>97 \%$ ). The HPLC purity of the combined and relyophilized fractions was typically $>99 \%$. The yield of the purification process was $53.3 \pm 1.7 \%(n=5)$. The $2 \mathrm{mmol}$ scale batch can be easily purified in 4 preparative HPLC runs.
The quality parameters for the three synthesized batches of DOTA-TATE are presented in Table 7. The synthesized batches of DOTA-TATE peptides were tested according to the specification, which was elaborated based on the requirements established by $\mathrm{Ph}$. Eur. for chemical precursors for radiopharmaceutical preparations (monograph No. 2902).

\section{CONCLUSIONS}

We have successfully developed an efficient method of the DOTA-TATE peptide synthesis using an automated peptide synthesizer equipped with a microwave oven.

The use of microwave radiation helped to achieve DOTA-TATE peptide with purity up to $80 \%$ and to expedite the peptide synthesis carried out on solid support - from 5 days to $5 \mathrm{~h}$. Furthermore, using an automated machine improved the repeatability of the process. During the study, the main impurities of the peptide were identified and the process was optimized to minimize them. 
The microwave process was scaled up and the maximum batch size was established on the level of 2 mmol scale. Due to the use of OxymaPure, the racemization level in the microwave-assisted process was maintained at the same level as in conventional room temperature peptide synthesis.

\section{Acknowledgments}

This work was partly financed by grant No. POIR/01.02.00-00-0041/15 ,Multivariate formulations of DOTATATE peptide as precursor for preparation of radiopharmaceuticals (MultiSom)" from the National Centre for Research and Development in Poland.

\section{Conflict of interest}

The authors declare no conflict of interest.

\section{REFERENCES}

1. Mittra E.S.: Am. J. Roentgenol. 211, 278 (2018).

2. Hirmas N., Jadaan R., Al-Ibrahemm A.: Eur. Nucl. Med. Mol. Imaging. 52, 190 (2018).

3. Esser J.P., Krenning E.P., Teunissen J.J., Kooij P.P.M., van Gameren A.L., et al.: Eur. J. Nucl. Med. Mol. Imaging. 33, 1346 (2006).

4. Baumann T., Rottenburger C., Nicolas G., Wild D.: Best Pract. Res. Clin. Endocrinol. Metab. 30, 45 (2016).

5. Chan W.C., White P.D.: Fmoc Solid Phase Peptide Synthesis, A Practical Appro, pp. 4176, Oxford University Press, New York 2004.

6. Subiros-Funosas R., Prohens R., Barbas R., ElFaham A., Albericio F.: Chem. Eur. J. 15, 9394 (2009).
7. Jad Y.E., Khattab S.N., de la Torre B.G., Govender T., Kruger H.G., et al.: Org. Biomol. Chem. 12, 8379 (2014).

8. De Leon-Rodriguez L.M.: Bioconjug. Chem. 19, 391 (2008).

9. Schottelius M., Schwaiger M., Wester H.J.: Tetrahedron Lett. 44, 2393 (2003).

10. Sosabowski J.K., Mather S.J.: Nat. Protoc. 1, 972 (2006).

11. Bacsa B., Desai B., Dibo G., Kappe C.O.: J. Pept. Sci. 12, 633 (2006).

12. Pedersen S.L., Tofteng A.P., Malik L., Jensen K.J.: Chem. Soc. Rev. 41, 1826 (2012).

13. Abu-Baker S., Garber P., Hina B., Reed T., Shahrokh G., et al.: Open J. Synth. Theory Appl. 3, 1 (2014).

14. Collins J., Porter K., Singh S., Vanier G.: Org. Lett. 16, 940 (2014).

15. Kumar A., Jad Y.E., Collins J.M., Albericio F., de la Torre B.G.: ACS Sustain. Chem. Eng. 6, 8034 (2018).

16. Wängler B., Beck C., Wagner-Utterman U., Scirrmacher E., Bauer C., et al.: Tetrahedron Lett. 2006, 47, 5985 (2006).

17. Sidorova M.V., Molokoedov A.S., Az'muko A.A., Kudryavtseva E.V., Krause E., et al.: Russ. J. Bioorg. Chem. 30, 101 (2004).

18. Ieronnymaki M., Androutsou M.E., Pantelia A., Friligou I., Crisp M., et al.: J. Pept. Sci. 104, 506 (2015).

19. Albert R., Jones P.S., Stolz B., Simeon C., Knecht H., et al.: Bioorg. Med. Chem. Lett. 8, 1207 (1998).

20. Stathopoulos P., Papas S., Tsikaris V.: J. Pept. Sci. 12, 227 (2006). 